\title{
FACTORS INFLUENCING THE USAGE OF ONLINE CLASS PLATFORMS AMONG THE COLLEGE STUDENTS IN COIMBATORE CITY
}

\author{
${ }^{1}$ Dr. R. Selvakumar, Mr. S. Balakrishnan, Dr. J. Thiagarajan, \\ ${ }^{2}$ Dr. S. Tamilarasi, Dr. S. Shankarii, \\ ${ }^{1}$ Assistant Professor of Commerce, ${ }^{2}$ Associate Professor, Hindusthan College of Arts \& \\ Science, Coimbatore, Tamil Nadu, India
}

\begin{abstract}
The world has witnessed a shift in the focus of Web applications towards social interaction, collaboration, and networking. The online class platform has become a new way of life in the field of education. Scholars and technocrats had identified the ways and means for the inclusion of various online class platform applications in the various utilities as well as in education. The tools range from general-purpose tools for the generic community of interest to highly specialized tools for the support of learning and others. The present study evaluated the factors influencing the usage of social networking sites among students who are pursuing higher education in Coimbatore city.
\end{abstract}

Keywords: Web Applications, Online class platform, and Higher Education.

\section{Introduction and Problem Statement}

The online class platform has been developed as an irreplaceable element in the life of humankind. It has helped in bringing out effective organization, communication, and awareness creation. Even in India, the Online class platforms created a wave to gather mass support against corruption and bring in a Bill in the parliament. The united voice was heard against crime against women, rape in particular was fought by creating a similar alarming public support at short notice. The recent floods in Chennai in December 2015 were overcome with pouring help from volunteers who networked through online class platforms outnumbering the victims. The revolutionary nature of online platforms is thus emerging to the limelight. On the other side of the coin, as truly stated to be a double-edged sword, the online class platform has traces of negative aspects as well. The most worrying probable fact is that of its Control. The consequences can be dangerous if utilized in a reckless irresponsible manner. Online class platform's nature is such that it allows enhanced social interaction thus allowing the user to voice out without being interrupted. This makes it interesting and addictive too. It attracts the crowd to keep networking with vigor. The less evident pitfalls of continued activity on the online class platforms need to be checkmated with wain the messes of the impact of individuals in particular and society in general through proper reins of control. The students, considered to be the mainstream element of growing society are directly or indirectly exposed to the online class platform. Hence the consequence posed by the Online class platforms on the day-to-day life of a student is immense and the 
analysis of which is inevitable. Hence, the present research will analyze the research questions down to earth and up of the hill considering the major concerns of the present situation.

Social network sites are web-based services that allow individuals to (1) construct a public or semi-public profile within a bounded system, (2) articulate a list of other users with whom they share a connection, and (3) view and traverse their list of connections and those made by others within the system. The nature and nomenclature of these connections may vary from site to site. Online class platforms are increasingly used by people in all walks of human life. The users are also enabled to identify others in the system with which they have a relationship. Social networking sites are often designed to be widely accessible. These sites are growing in popularity worldwide according to recent empirical evidence. Online class platforms have revolutionized the life of many people and thus attracted much attention, not only from industry but also academia. Scholars have examined the role of online class platforms in contemporary society based on certain theories. They have used research constructs and developed conceptual frameworks in their studies.

The Online class platforms are all-pervasive and cover a wide range of research topics. Online class platforms have become increasingly popular because of the combination of both technological developments and social change. The present investigation was carried out based on a conceptual model which states that an accurate understanding of Online class platform literacy requires more insight into people's access to Online class platform applications, knowledge, skills, self-efficacy, attitudes, and actual media use. The uses and gratifications of the Online class platform concerning college students in Coimbatore city are being examined based on the theory proposed by previous researchers. The scholar observed that online class platforms can be utilized in gaining the maximum value of social relationship management. The theory states: "The emergence of new online class platform technologies allows businesses to change the way they relate to people, shifting the focus from managing transactions to building deeper relationships". With the above setting the present research is intended to find the solution for the following research objective;

- To examine the factors influencing the students to use online class platforms.

\section{Literature reviews}

Akakandelwa and Gabriel (2017) expressed that Online class platform has become omnipresent and almost inescapable, revolutionizing the way students communicate, interact and socialize; and has become an integral part of their social and cultural fabric. Consequently, students are spending a substantial part of their time on Online class platforms. University students and youth are considered the largest users of these technologies. Despite a growing corpus of literature on the usage of Online class platform around the world, there is a dearth of research in Zambia on how Online class platform affects students' social life. The study also found that more than half of the students found themselves saying "just a few more minutes" when using Online class platforms, checked their Online class platform sites before doing something else, felt their academic productivity suffered because of Online class 
platform, failed to cut down on time spent on Online class platform, received negative comments from others about their use of Online class platform and felt stressed out due to Online class platform use.

Simonson et al. (2000) described online learning tools as more effective than traditional classroom learning (using a textbook for learning) because of the availability of the line materials and 24 hours access to learning. Students are more likely to use this Online class platform such as YouTube for their informal learning. YouTube provides video for information and knowledge that extends beyond the limit of the classroom and textbook. It also provides ta tutorials and shows the students clearly how certain things are done through the video uploaded. The ease of accessing out of textbook information the ease of sharing information and the availability of these online materials at one own time are the other reasons why students preferred to use this Online class platform as the tool for their informal learning.

\section{Hypothesis}

$\mathbf{H}_{1}$ : There is no difference between the factors influencing the respondents towards the usage of online class platform sites and their demographic profile

\section{Research Design}

The study is both analytical and descriptive. Primary data has been used in this study using a well-structured questionnaire, to make analysis. Secondary data for the study has been collected from books, magazines, websites, reports, and business journals. The population targeted for this study is college students who use online class platforms for various uses of managing societal relationships. A total of 150 respondents from the city are being selected and to whom the questionnaires are distributed. The sampling technique adopted for the study is purposive or judgment sampling. It is so because; only the college students who use online class platforms for various purposes are being included as samples in the study. The statistical tools used for the study are Simple Percentage analysis, Factor analysis, and Analysis of Variance.

\section{Limitations of the study}

The following are the limitations of the study:

1. This research was location-specific and was confined to the city of Coimbatore in the state of Tamil Nadu in India. Hence the results of this research may not apply to other parts of the globe.

2. The primary data collected depicts the attitude of the respondents which may be self-biased.

Table 1: Demographic Profile of the Respondents

\begin{tabular}{|l|c|c|}
\hline Classification & No of Respondents & Percentage \\
\hline Gender & 86 & 57.3 \\
\hline Male & 64 & 42.7 \\
\hline Female & \multicolumn{2}{|l|}{} \\
\hline
\end{tabular}




\begin{tabular}{|c|c|c|}
\hline \multicolumn{3}{|l|}{ Age (Years) } \\
\hline Less than 18 & 07 & 04.6 \\
\hline $18-20$ & 67 & 44.7 \\
\hline $21-23$ & 49 & 32.7 \\
\hline Above 23 & 27 & 18.0 \\
\hline \multicolumn{3}{|l|}{ Marital Status } \\
\hline Married & 28 & 18.7 \\
\hline Unmarried & 122 & 81.3 \\
\hline \multicolumn{3}{|l|}{ Domain of Education } \\
\hline Science & 21 & 14.0 \\
\hline Social Studies & 86 & 57.3 \\
\hline Law and others & 43 & 28.7 \\
\hline \multicolumn{3}{|l|}{ Type of education } \\
\hline Under graduation & 47 & 31.3 \\
\hline Post Graduation & 40 & 26.7 \\
\hline Research & 35 & 23.3 \\
\hline Diploma and others & 28 & 18.7 \\
\hline \multicolumn{3}{|l|}{ Educational Institution } \\
\hline Government-aided & 47 & 32.0 \\
\hline Self-financing & 72 & 48.0 \\
\hline University & 31 & 20.0 \\
\hline \multicolumn{3}{|l|}{ Residence } \\
\hline Rural & 62 & 41.3 \\
\hline Urban & 88 & 58.7 \\
\hline Total & 150 & 100.0 \\
\hline
\end{tabular}

Source: Compiled and calculated using primary data

The above table represents the demographic profile of the respondents who are the students using the online class platforms for their varied purposes in Coimbatore city. Out of 150 samples selected 57 percent of the Respondents are male, 44.7 percent of the respondents are between the age of 18 to 21 years. 81.3 percent of the respondents are unmarried, 57.3 percent of the respondents belonged to social studies as their educational domain, 31.3 percent of the respondents are doing they're under graduation and around 48.0 are doing their education in self-financing colleges. The majority of respondents at 58.7 percent are from urban residences.

\section{Factors influencing the usage of Online class platforms among the students Kaiser - Meyer - Olkin (KMO) and Barlett's Test}

The Kaiser - Meyer - Olkin (KMO) and Barlett's Test are the measures of sampling adequacy, which varies between 0 and 1 . The test provides a minimum standard to proceed with factor analysis. The results are shown in the table below. 
Table 2: Kaiser - Meyer - Olkin (KMO) and Barlett's Test Results

Kaiser-Meyer-Olkin Measure of Sampling Adequacy

\begin{tabular}{|l|r|}
\hline Approx. Chi-Square & 12.321 \\
\hline df & 256 \\
\hline Sig. & $\mathbf{. 0 0 0}$ \\
\hline
\end{tabular}

Source: Compiled and calculated using primary data

KMO and Barlett's test result shows that p-value as .000 which is significant. Test of sampling adequacy shows the value as .713 which means the sample is adequate and can proceed with factor analysis.

Table 3.: Total Variance Explained

\begin{tabular}{|c|c|c|c|c|c|c|c|c|c|}
\hline \multirow{2}{*}{ Component } & \multicolumn{3}{|c|}{ Initial Eigenvalues } & \multicolumn{3}{|c|}{$\begin{array}{c}\text { Extraction Sums of Squared } \\
\text { Loadings }\end{array}$} & \multicolumn{3}{|c|}{$\begin{array}{c}\text { Rotation Sums of Squared } \\
\text { Loadings }\end{array}$} \\
\hline & Total & $\begin{array}{c}\% \text { of } \\
\text { Variance }\end{array}$ & $\begin{array}{c}\text { Cumulative } \\
\%\end{array}$ & Total & $\begin{array}{c}\% \text { of } \\
\text { Variance }\end{array}$ & $\begin{array}{c}\text { Cumulative } \\
\%\end{array}$ & Total & $\begin{array}{c}\% \text { of } \\
\text { Variance }\end{array}$ & $\begin{array}{c}\text { Cumulative } \\
\%\end{array}$ \\
\hline 1 & 7.030 & 37.001 & 37.001 & 7.030 & 37.001 & 37.001 & 4.094 & 21.549 & 21.549 \\
\hline 2 & 2.705 & 14.236 & 51.236 & 2.705 & 14.236 & 51.236 & 3.582 & 18.853 & 40.403 \\
\hline 3 & 1.847 & 9.720 & 60.956 & 1.847 & 9.720 & 60.956 & 3.154 & 16.602 & 57.005 \\
\hline 4 & 1.630 & 8.578 & 69.534 & 1.630 & 8.578 & 69.534 & 2.381 & 12.530 & 69.534 \\
\hline 5 & .930 & 4.896 & 74.430 & & & & & & \\
\hline 6 & .798 & 4.201 & 78.632 & & & & & & \\
\hline 7 & .647 & 3.405 & 82.037 & & & & & & \\
\hline 8 & .603 & 3.175 & 85.212 & & & & & & \\
\hline 9 & .508 & 2.672 & 87.884 & & & & & & \\
\hline 10 & .462 & 2.430 & 90.314 & & & & & & \\
\hline 11 & .431 & 2.268 & 92.583 & & & & & & \\
\hline 12 & .367 & 2.235 & 94.818 & & & & & & \\
\hline 13 & .244 & 2.165 & 96.983 & & & & & & \\
\hline 14 & .231 & 1.916 & 98.899 & & & & & & \\
\hline 15 & .265 & 1.101 & 100.00 & & & & & & \\
\hline
\end{tabular}

Source: Compiled and calculated using primary data

The above table exhibits the result of factor analysis with principal component analysis of 15 items of factors influencing air travel with 4 factors which extracted out, by the 
Eigenvalues, such as $7.030,2.705,1.847$, and 1.630 respectively are greater than the recommended level of 1 .

\section{Rotated Component Matrix}

Rotated Component Matrix indicated the correlation of each variable with each factor. After factor analysis, four factors have arrived from fifteen statements. Variable with high factor loading are considered first and have great importance. Such factors are identified names are given for each factor and the results are shown in the following table.

Table-4.: Rotated Component Matrix

\begin{tabular}{|c|c|c|c|c|}
\hline \multirow{2}{*}{ Factors } & \multicolumn{4}{|c|}{ Component } \\
\hline & 1 & 2 & 3 & 4 \\
\hline Quality of the content delivered & .328 & 674 & -.222 & .128 \\
\hline Relevance to society and education & .464 & .277 & .691 & .490 \\
\hline Reliability and accuracy of the information & -.295 & .666 & .440 & -.353 \\
\hline Faster approach to the masses & -.073 & -.136 & -.358 & .730 \\
\hline Getting social attention in no time & .288 & -.529 & .627 & -.266 \\
\hline Innovative and creative ways of learning & .723 & -.229 & .401 & -.325 \\
\hline $\begin{array}{l}\text { If I find the sites helpful, I would shop } \\
\text { impulsively }\end{array}$ & .640 & -.418 & .003 & .377 \\
\hline User-generated contents & 670 & -.299 & -.246 & .349 \\
\hline Effective and efficient testing methods & .770 & .273 & .097 & -.243 \\
\hline Well-designed and updated sites. & .697 & .217 & .405 & -.224 \\
\hline Global access to various resources & .450 & -.116 & -.319 & .631 \\
\hline Cross-cultural relationships & .487 & -.396 & .479 & .623 \\
\hline Less dependence on printed materials & .401 & .101 & .676 & .388 \\
\hline Skill development & -.020 & .094 & .652 & .439 \\
\hline Comfortability in the ease of use & .362 & .599 & .055 & .032 \\
\hline
\end{tabular}

Extraction Method: Principal Component Analysis.

Rotation Method: Varimax with Kaiser Normalization.

a. Rotation converged in 6 iterations.

The result of factor analysis with the extraction technique of Principal Component Analysis as well as the Rotated Component Matrix based on Varimax Rotation Technique with Kaiser Normalization identified four factors identified with new names. Factor one consists of five items, Innovative and creative ways of learning, If I find the sites helpful, I would shop impulsively, User-generated content, Effective and efficient testing methods, and well-designed and updated sites are named as Design factors. 
Factor two consists of three items; Quality of the content delivered, Reliability and accuracy of the information, and Comfortability in the ease of use are named Quality factors.

Factor three consists of four items; Relevance to society and education, getting social attention in no time, less dependence on printed materials, and Skill development are named as Outlook factors.

Factor four consists of three items; faster approach to the masses, Global access to various resources, and Cross-cultural relationships are named as Outreach factors.

\section{Factors influencing the students towards Online class platform usage: Analysis of Variance}

The present section analyses the differences in the factors influencing the respondents towards the usage of online class platforms based on their demographic classification with the help of the following hypothesis.

H1$_{1}$ : There is no difference between the factors influencing the respondents towards the usage of online class platform sites and their demographic profile

Analysis of variance

\begin{tabular}{|l|c|c|c|}
\hline \multicolumn{1}{|c|}{ Variables } & F & P-value & S/ NS \\
\hline Gender & .255 & .002 & $\mathrm{~S}^{* *}$ \\
\hline Age & 12.111 & .000 & $\mathrm{~S}^{* *}$ \\
\hline Marital status & 16.251 & .025 & $\mathrm{~S}^{*}$ \\
\hline Educational Domain & .982 &. .002 & $\mathrm{~S}^{* *}$ \\
\hline Type of education & .551 & .000 & $\mathrm{~S}^{* *}$ \\
\hline Educational institution & 3.595 & .007 & S $^{* *}$ \\
\hline Monthly Income & .484 & .046 & $\mathrm{~S}^{*}$ \\
\hline Residence & .451 & .012 & $\mathrm{~S}^{*}$ \\
\hline
\end{tabular}

*Significant at 5 percent level **Significant at 1 percent level

Source: Compiled and calculated using the primary data

The table above represents the analysis of association using analysis of variance between the factors influencing the online class platform usage and the demographic profile of respondents. It is clear from the table that all the personal profiles; are found significant at 1 percent and 5 percent levels respectively. Hence the null hypothesis is rejected and concluded that the association between factors influencing the online class platform usage and the demographic profile of respondents is significant.

\section{Conclusion and Recommendation}

The online class platform has fastened the pace at which people communicate, socialize, learn, and conduct business. People have started to share on online class platforms and in virtual environments with technology everywhere in daily life as of all the social networks. The online class platform has become inevitable, revolutionizing the way students converse, interrelate, and hang out in the global village. While doing so, students are spending a considerable part of their time on online class platforms. The purpose varies between the students and it is found that rather than learning, the students spend most of their time in various utility services using the Online class platforms. However, to be reasonable and legit we have to say that online life has its positive results and has its disadvantages too. 
Based on the findings of this study, it is recommended that the institutions must develop policies that encourage innovative usage of Online class platform for educational purposes such as group discussions, group research projects, etc. whilst minimizing its negative impact on students by controlling Online class platform use among students during learning sessions.

\section{References}

1. Akakandelwa Akakandelwa and Gabriel Walubita (2017), Students' Online class platform Use and its Perceived Impact on their Social Life: A Case Study of the University of Zambia, The International Journal of Multi-Disciplinary Research ISSN: 3471-7102, pp 1- 14

2. Bacarella, Christian V., et al. "Online class platform? It's Serious! Understanding the Dark Side of Online class platform.” European Management Journal, vol. 36, no. 4, 2018, pp. 431-438., doi:10.1016/j.emj.2018.07.002.

3. Chiou, Wan-Jiun Paul, et al. "Paying Attention to Online class platform Stocks." International Review of Economics \& Finance, 2018, doi:10.1016/j.iref.2018.08.009.

4. Çakır, Recep, and S. Serkan Tan. "Development of Educational Applications on the Social Network of Facebook and Its Effects on Students' Academic Achievement." Educational Sciences: Theory \& Practice, vol. 17, no. 5, Oct. 2017, doi:10.12738/estp.2017.5.0273.

5. Al-Bahrani, Abdullah, et al. "Engaging Students Using Online class platform: The Students' Perspective." International Review of Economics Education, vol. 19, 2015, pp. 36-50., doi:10.1016/j.iree.2015.06.001.

6. Carolan, Brian V. "Estimating the Effects of Students' Social Networks: Does Attending a NormEnforcing School Pay Off?” The Urban Review, vol. 42, no. 5, Sept. 2009, pp. 422440., doi:10.1007/s11256-009-0141-2. 